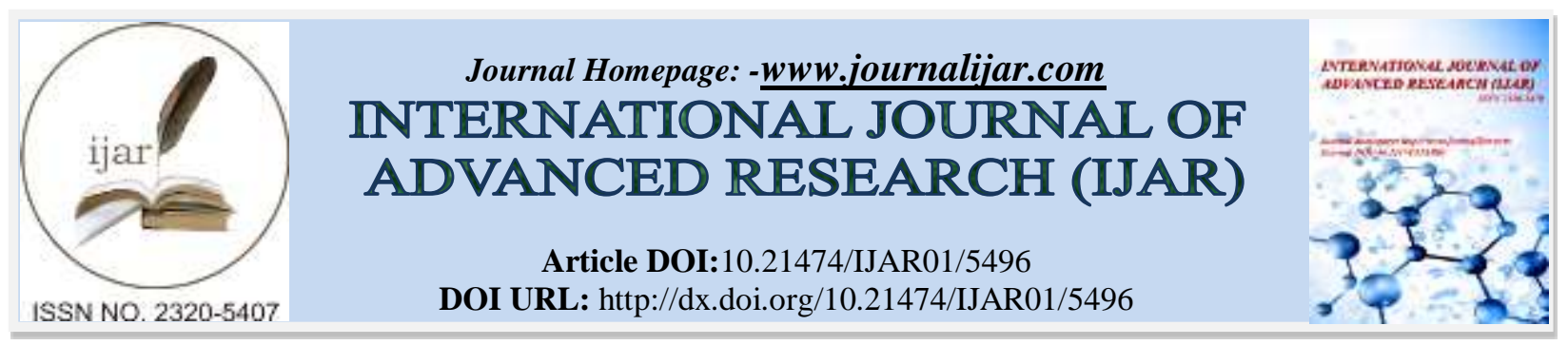

RESEARCH ARTICLE

\title{
CLINICAL PROFILE AND OUTCOME OF SACROCOCCYGEAL TERATOMA IN CHILDREN.
}

Dr. Arun kumar Rajakantham and Dr. Sriram.

\section{Manuscript Info}

Manuscript History

Received: 22 July 2017

Final Accepted: 24 August 2017

Published: September 2017

Key words:-

Sacro Coccygeal Teratoma, Altman type, tumor marker

\begin{abstract}
The primary aim is to analyze the clinical profile including epidemiology, clinical presentation, diagnosis (ante natal and post natal), operative findings, and outcome.

SCT are a relatively uncommon tumor. Those presenting within a few days of birth carry a better prognosis. Mass is the most common presenting symptom. Early diagnosis, prompt surgical intervention gives good result and long term survival. The optimal therapeutic program for children with malignant SCT is still evolving.
\end{abstract}

Copy Right, IJAR, 2017,. All rights reserved.

\section{Introduction:-}

SacrococcygealTeratoma is a neoplasm arising from the caudal end of spine, usually protruding from the inferior end of the spinal column and displacing the anus forwards.

Sacro Coccygeal Teratoma is defined as a tumor emerging from the proliferation of pluri potent cells. They contain tissues from one or more germ cell layers.

Though rare it is the most common tumor in the new born period with incidence of 1:35000-45000 live births. Male female ratio is 1: 3-4. They are composed of 2 or 3 germ cell layers, having multiple tissue types. They present in varying sizes and shapes.

Sacro Coccygeal Teratoma is tumor of new born which carries good prognosis if diagnosed early and adequate surgical treatment is prompt.

\section{Materials And Methods:-}

Study population: All patients who presented to our hospital with sacrococcygealteratoma.

Number of cases: 15 .

Study period:-

December 2011 to December 2013.

Exclusion Criteria: All sacro coccygeal tumors not proven to be teratoma e.g. Hind gut duplication cyst, Dermoid, Meningocele, Pelvic tumors - Neuroblastoma. 
Screening Procedure: All cases of sacro-coccygeal tumors were examined in detail and subjected to X-ray Pelvis and chest, Ultra sonogram, CT / MRI and alpha feta protein.

\section{Follow Up:-}

Monthly follow up for 1 year, then two monthly follow up till the end of the study.

\section{Methodology:-}

All cases of Sacro coccygeal teratoma detected both ante natally and post natally were examined clinically.

\section{Investigation protocol:-}

All the patients underwent the following investigations-

$\mathrm{X}$ ray chest, Ultra sonogram of abdomen, pelvis and the swelling and CECT / MRI if feasible. The tumor markers alpha feta proteins, beta HCG and LDH were done. Cardiac evaluation was done before surgery. Genetic work up was also done. The patients then went for management as per the protocol either upfront surgery or surgery after neo adjuvant chemotherapy.

The standard procedure was WIDE LOCAL EXCISION WITH COCCYGECTOMY. Type I and II were approached from the perineum. Type III and Type IV were approached initially through abdomen and followed externally as required. Neo adjuvant chemotherapy was given for inoperable tumors and metastatic tumors. Adjuvant chemotherapy with or without radiotherapy was given based on the grade of the tumor and the resection margins positivity.

All the patients were followed till the end of 2 years of study.

\section{Observations And Results:-}

\section{Age:-}

In our study 12 patients $(80 \%)$ were diagnosed before one month of ageand the remaining 3 patients were diagnosed later.

\begin{tabular}{|l|l|}
\hline Age & No of Patients \\
\hline Day 1 & 6 \\
\hline Day 3-11 & 5 \\
\hline Day 24 & 1 \\
\hline 8 months & 1 \\
\hline 1 year & 2 \\
\hline
\end{tabular}




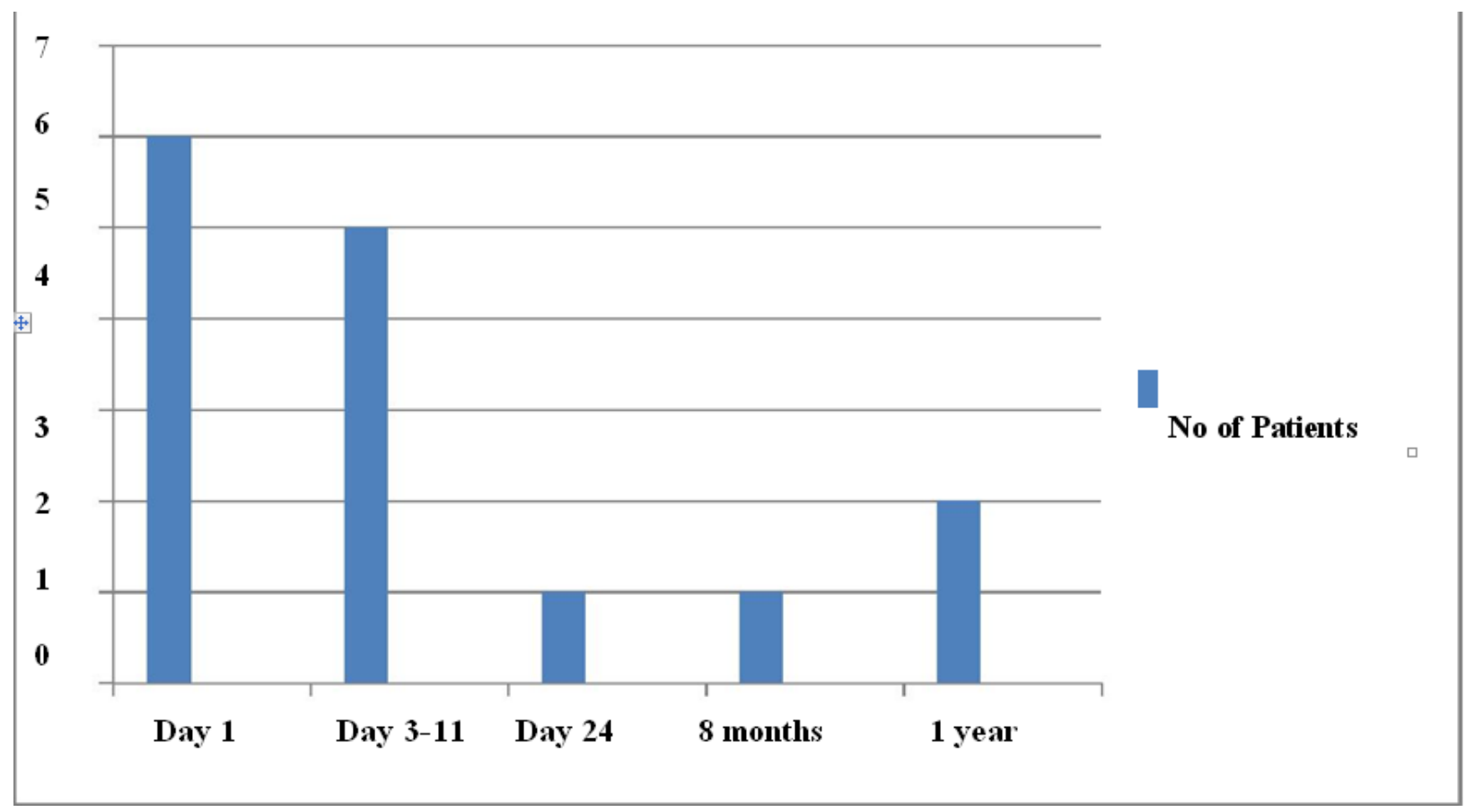

Gender Predilection:-

In our study sacrococcygealteratoma were more common in females (13) than in males (2).

The ratio $\mathrm{M}: \mathrm{F}$ is $1: 6.5$

\begin{tabular}{|l|l|}
\hline Male & 2 \\
\hline Female & 13 \\
\hline
\end{tabular}

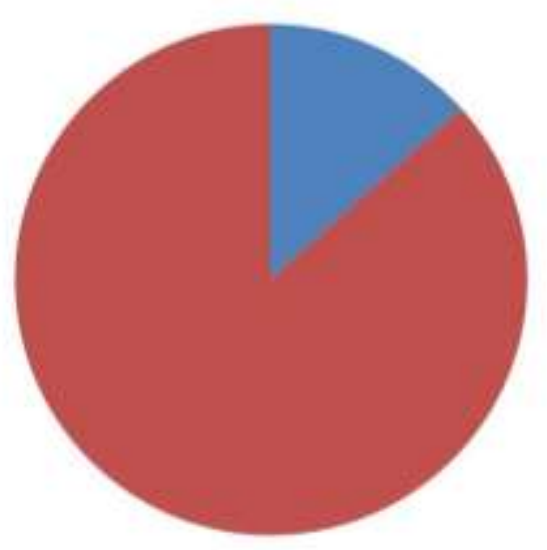

\section{Diagnosis:-}

In our study two cases were detected antenatally, and others were diagnosed postnatally. One neonate of a twin pregnancy had sacrococcygealteratoma detected in the post natal period.

\begin{tabular}{|l|l|}
\hline Ante natally diagnosed & 2 \\
\hline Post Natally diagnosed & 13 \\
\hline
\end{tabular}




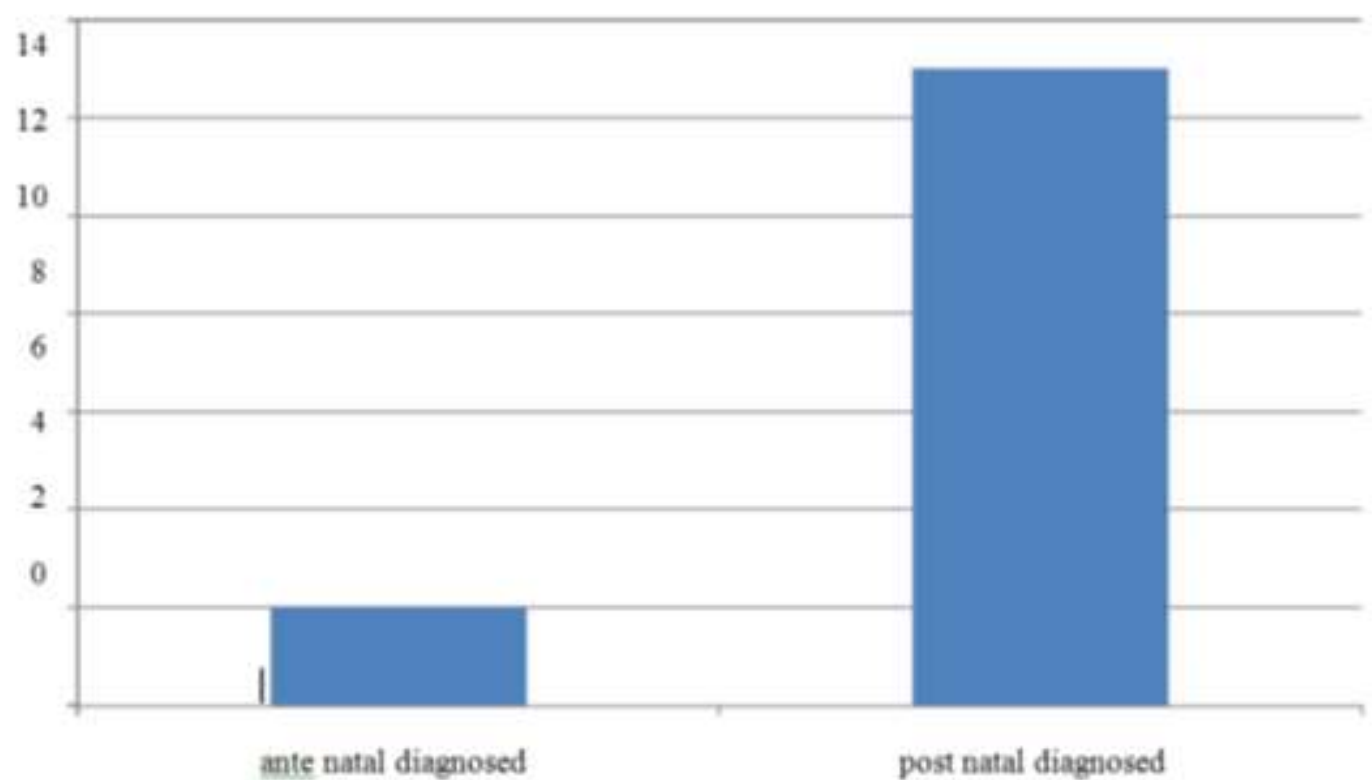

\section{Clinical Features:-}

Though ante natal diagnosis is the most common mode of detection but in our study 12 patients were diagnosed in the neonatal period of which two had been diagnosed by ante natal ultra sonogram and the rest postnatally. 3 patients were diagnosed when they presented with constipation and obstructive urinary symptoms.

\begin{tabular}{|l|l|}
\hline \multicolumn{1}{|c|}{ Diagnosis } & \multicolumn{1}{c|}{ Patients } \\
\hline Ante natally & 2 \\
\hline Neonatal period & 10 \\
\hline Infancy & 3 \\
\hline
\end{tabular}

\section{Altman Type:-}

In our study we found type 2 to be the commonest (46\%) and type 4 to bethe least common (6\%).

\begin{tabular}{|l|l|l|}
\hline \multicolumn{2}{|l|}{ Type 1 } & 4 \\
\hline \multicolumn{2}{|l|}{ Type 2 } & 7 \\
\hline Type & 3 & 3 \\
\hline Type & 4 & 1 \\
\hline
\end{tabular}




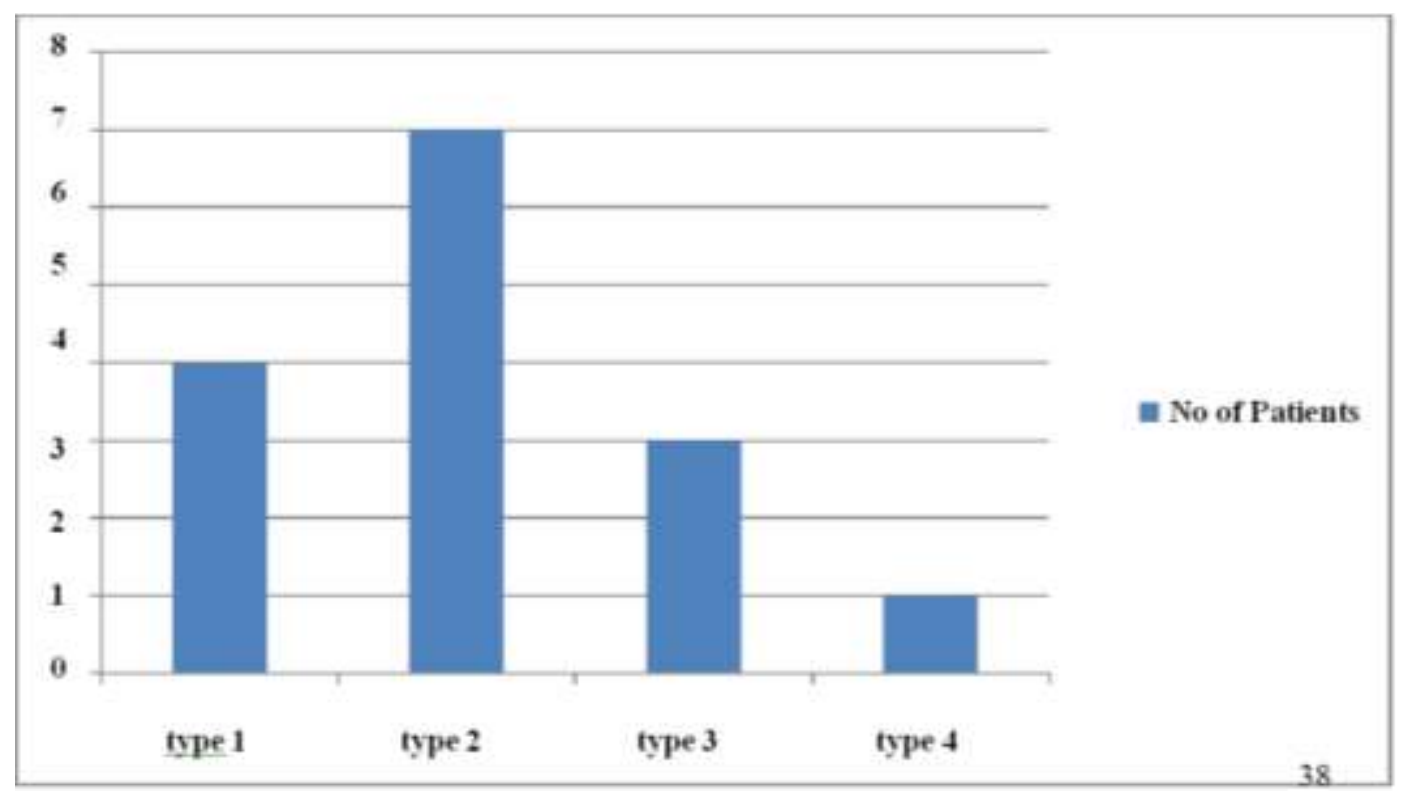

Histological types:-

In our study comprised 10 patients $(66 \%)$ had mature teratoma.

\begin{tabular}{|l|l|}
\hline Mature teratoma & 10 \\
\hline Immature teratoma & 5 \\
\hline
\end{tabular}

\section{Discussion:-}

Sacrococcygealteratoma is a congenital tumor. Incidence is 1 in 40,000 new born. It arises from the caudal end of the spine with different sizes and shapes of protrusion. Most of them are benign and well differentiated and hence have a good prognosis after complete surgicalexcision. ${ }^{2}$

It is composed of one or more germinal cell layers originating from pluripotential cells, yet it lacks complex tissular organization. The new born with Sacrococcygealteratoma has excellent prognosis depending on the time of diagnosis and when the surgery was performed, the malignant potential of the tumor and the ease with which surgical resection wasperformed .

Although about $75 \%$ of cases are seen in females, the exact reason for the female preponderance is not fully understood. ${ }^{3}$ Apart from age at diagnosis and treatment, and the extent of resection, the prognosis is also determined by the histological type andAltman type at the time of resection, and not the size of the tumor Follow up in patients with SCT is necessary especially during thefirst three years of treatment when recurrence is most likely.

Extensive surgery in the pelvic and perineal region may involve disruption of nerves and muscles which supply the urinary /ano rectal sphincters which are necessary for continence. Our follow up period was for 2 years and we did not encounter any incontinence to micturition and defecation. Longer period of follow is however required, to identify late incontinence problem to micturition and defecation.

\section{Conclusion:-}

1. SacrococcygealTeratomas are a relatively uncommon tumor affecting neonates, infants and children. Sacrococcygealteratoma has a female preponderance.

2. Those presenting within a few days of birth carry a better prognosis than those detected later in infancy.

3. Benign SacrococcygealTeratomas generally have a favorable prognosis.

4. Benign Teratomas have a significant recurrence rate mandating follow up for more than 3 years.

5. Most of Sacrococcygealteratoma present within the first few weeks of life.

6. Mass is the most common presenting symptom.

7. Early diagnosis, prompt surgical intervention, gives good results and long term survival. 
8. Lower segment caesarian section as the mode of delivery is considered when the size of the mass is more than the Bi parietal Diameter of the fetus. When there are no other obvious indications for Lower segment caesarian section, normal vaginal delivery is considered.

9. Among the associated anomalies, the most common anomaly is renal anomaly.

10. With advancing radiological imaging, early diagnosis is possible followed by appropriate management and long term survival.

11. The overall survival of neonatal sacrococcygealteratoma is high.

12. Tumor markers are used for monitoring the disease rather than the assessment of the grade of the disease.

13. Important components of management include timely diagnosis, multidisciplinary planning, (surgery, radiotherapy and chemotherapy) long term follow up, and intervention for functional sequelae.

14. Poor prognostic factors include solid tumor, those detected early in pregnancy, malignant histotypes, polyhydramnios, placentamegaly, and fetal hydrops.

15. Surgical resection alone is adequate therapy for non metastatic malignant tumor.

16. Cisplatin based chemotherapy has improved the survival of patients with malignant tumor.

17. Surgery alone is inadequate for successful management of children with malignant sacrococcygealteratoma. Chemotherapy with PEB

18. (Cisplatin,Etoposide, Bleomycin) can be effective when combined with radiation, but fatal pulmonary toxicity can result from such combined therapy.

19. After Surgery sequelae of Sacrococcygealteratoma tends to improve with time.

20. While sacrococcygealteratoma is usually benign, recurrent malignant transformation in patient who present late and long term functional sequelae are problems that must be tackled by the care givers.

21. The optimal therapeutic program for children with malignant SCT is still evolving.

\section{Bibliography:-}

1. GatcombaHG,Assikis V, Kooby D, Johnstone PA, Primary retroperitoneal teratoma,A review of literature.J.SurgOncol 2004;86:107-113.

2. Dehner L.P.: Gonadal and extragonadal germ cell neoplasms: Teratomas inchildhood. In: Finegold M., ed.Pathology ofNeoplasia in Children andAdolescents, Philadelphia: WB Saunders; 1986:282-312.

3. Isaacs H.: Germ cell tumors. In: Isaacs H., ed. Tumors of the Fetus andNewborn, Philadelphia: WB Saunders; 1997:15-38.

4. Skinner M.A.: Germ Cell tumors. In: Oldham K.T., Colombani P.M.,Foglia R.P., ed. Surgery of Infants and Children: Scientific Principles andPractice, Philadelphia: Lippincott-Raven; 1997:653-662. 